\title{
Transgression of Sexual Parameters in Lord
}

\section{Byron's Lara}

\section{Dr. Savo Karam}

Associate professor, The Lebanese University, Lebanon

\author{
"Sexuality is power." (Marquis de Sade) \\ "It is only by sacrificing everything to sensual pleasure \\ that this being known as Man, cast into the world in spite \\ of himself, may succeed in sowing a few roses on the thorns of \\ life." (Marquis de Sade)
}

\begin{abstract}
The presence of both taboo and transgression has been pervasive in literature. Although a natural process, sexuality remains a mysterious reality, lying dormant under the linings of various literary works that explicitly insinuate at wild passionate love, uncontrollable desires and overflowing ecstasy. A flamboyant poet such as Lord Byron, whose poetry has gained erotic resonance, is no exception. In his Letters and Journals, he describes poetic creation as "the lava of the imagination whose eruption prevents an earthquake;" such erogenous metaphor reveals a lot about the poet's sexual identity, passionate appetite and sensual creativity. Undoubtedly, Byron's multifaceted sexual identities and complex sexual engagements assume a creative/mythical projection throughout his poetic art that crystallizes in his insinuation at epicene or third sex. To camouflage his ambiguous sexual inconsistencies, his predominant queer passion and protean desires, Byron implements his rigorous sexual fantasy and portrays transgendered sexuality in his tales and poetic oeuvre. This paper calls for a critical reading/rumination of a third gender incarnated in the sexually transgressive character of the foreign-born page Kaled who possesses queer psycho-sexual traits since s/he is transvestic, androgynous and pandrogynous.
\end{abstract}

Keywords—Lord Byron, androgyny, transvestism, pandrodgyny/epicene, transgression, Lara.

\section{INTRODUCTION}

Is desire a conventional dynamic necessity or is it an unconventional daring deviation? The American gender theorist, Judith Butler, claims in Subjects of Desire: "to desire is to err, but to err necessarily" (qtd. in Tomasch and Gilles 385). In this respect, it is interesting to note that Lord Byron himself feels guilty and responsible for his sexual deviancy, as he explicitly and dejectedly confesses his sin to his half-sister Augusta Leigh to whom he addresses, saying:

The fault was mine; nor do I seek to screen My errors with defensive paradox;

I have been cunning in mine overthrow, The careful pilot of my proper woe.

("Epistle to Augusta" III)

Byron's hidden sexual impulses or desires are secretly confessed in his narrative poem Lara in a manner that manifests Michel Foucault's assertion that "We have... invented a different kind of pleasure: pleasure in the truth of pleasure... of captivating and capturing others by it, of confiding it in secret" (Foucault 1: 71). There exists, therefore, an additional quality to a poem that pleases and delights which is the pleasure of "luring it [the secret] out in the open- the specific pleasure of the true discourse on pleasure" (Foucault 1: 71). This furtiveness is further heightened by the fact that Lara was published anonymously with Jacqueline, written by Samuel Rogers, after the $5^{\text {th }}$ of August in 1814.

Taboo-free society and transgression-free literature are an unrealistic representation of a Utopian dream as established by the numerous published works which dominated the literary scene. D. H. Lawrence's novel Lady Chatterley's Lover, Howard Brenton's The Romans in Britain, Albert Camus' The Stranger, Oscar Wilde's The Picture of Dorian Gray, Edward Bond's Saved, Horace Walpole's Mysterious Mother, Henry Miller's Tropic of 
Cancer, Daniel Defoe's Moll Flanders, Fanny Burney's Evelina, Vladimir Nabokov's Lolita, Salman Rushdie's Satanic Verses and Hanif Kureishi's The Black Album are only a few examples.

Essentially, taboos are indispensable to the social set-up and have been considered progressive in the sense that they develop and evolve. Gerd-Klaus Kaltenbrunner affirms that the "complete removal of taboos would destroy the fabric of human society. One taboo could be replaced by another, even the conversion of taboos from negative into positive ones (or vice versa) is possible, but taboos cannot be eliminated from people's lives" (qtd. in Horlacher, Glomb, and Heiler 14). As such, sexual transgression has evolved from social taboos that are secretly manifested in deviant sexual desires.

Byron lived in a Victorian bourgeois environment where "sexuality was carefully confined... On the subject of sex, silence became the rule... The couple... safeguarded the truth, and reserved the right to speak while retaining the principle of secrecy" (Foucault 1: 3). Against this sexually repressive atmosphere, Byron gave vent not only to his own secret but also to that of the sexual collective unconscious of Victorian prudery. Challenging the traditional social norms of gender and sexuality, Byron offers a window into both his unconscious and that of his readers to reveal that sexuality in all its forms, deviant or otherwise, is a reflection of human nature. As a sexually licentious poet, he encourages masculine and feminine sexual freedom; more specifically, through variations of gender fluidity, he valorizes the female's sexual power, allowing her the ultimate freedom to smoothly penetrate strict gender boundaries.

In Gender Trouble: Feminism and the Subversion of Identity, Butler states there is a concrete or solid relationship between gender and sexuality where gender is determined by repeated social acts: "a corporeal style, an "act," as it were, which is both intentional and performative, where "performative" suggests a dramatic and contingent construction of meaning" (139). Butler further elaborates that gender is a practice: "gender proves to be performative - that is, constituting the identity it is purported to be. In this sense, gender is always a doing" (33). On her part, Simone de Beauvoir asserts that "One is not born, but rather becomes, a woman" suggesting the acquired nature of gender as a matter of attitude; hence, the repetition of cultural performative acts decide gender identity. In applying Butler's performative theory of gender to Kaled, it is possible to highlight gender as socially constructed, revealing the repressed desires of both males and females through a dynamic character who assumes a social metamorphosis. More significantly, what is ultimately grasped is an individual that has more than one sex or an indefinite/neutral sex, what is known as a third gender. Consequently, Byron's Lara seems to enact Luce Irigaray's essay entitled "This Sex Which Is Not One" suggesting that lovers become a "living mirror" (207) or each other's replica in a manner that: "[o]ne cannot be distinguished from the other" (209). This analysis attempts to locate Butler and Irigaray's radical views that are used to uncover the possibility of the existence of pandrogyny as a third gender developing from transvestitism and androgyny.

It is worthwhile to draw attention to Byron's reverence for the Greeks which reaches its height when he decides to enlist in their struggle for independence. He must have been aware "that a Greek could, simultaneously or in turn, be enamored of a boy or a girl... what made it possible to desire a man or a woman was simply the appetite that nature had implanted in man's heart for 'beautiful' human beings, whatever their sex might be" (Foucault 2: 188). Lara functions as a public arena where Byron poetically merges both genders beneath the guise of a simple love-story that does not stray from Victorian principles. It could be inferred that the issue of gender tension is not only figurative but also personal as Byron craftily finds an appropriate outlet for his repressed multifaceted sexuality. In fact, he seeks to portray sexuality as independent of sexual bounds and to closet his unusual sexual inclinations, his dark secrets in Lara, thereby arousing the curiosity of his reading public.

Additionally highlighting Byron's affinity to the Greeks is the fact that he entitled his poem Lara who, according to Greek mythology, is a female. What is striking, therefore, is that 'Kaled,' a masculine name, provided to a female character who reveals her true identity towards the end, while Lara is the constant male protagonist. There are, therefore, two performative functions at play in this poem, the naming and dress-codes of individuals in society. Consequently, though Cheryl Giuliano claims that Kaled's male-attire indicates "a woman who subscribes to patriarchal codes... mirrors narcissistic masculine desire" and also reflects Byron's misogyny (786); yet, considering Byron's individual sexual inclinations, both Lara and Kaled are Byron's mirror image, as a heterosexual and bisexual.

Furthermore, William Lofdahl has attempted to redefine androgyny as the third sex in Byron's poetry, while Giuliano claims that Lady Caroline Lamb is generally acknowledged as the real image of Kaled and is "even more clearly epicene" (787). However, this cannot be the case since the Byronic third sex applies to the union of the 
physical, spiritual and emotional attributes of lovers who are enjoined in one and become each other's mirror-image.

Renowned for breaking social laws and for provoking his readers' imagination, Byron interrogates social conventions and boundaries in the way he masculinizes females and simultaneously feminizes males. Through these gender games, he entices his readers' appetites, arouses their libidinous fantasy and makes them crave more images of the twist of gender demarcation/discrimination as is the case in Lara. Byron's readers are mesmerized and fascinated by various signs of transgression. After all, had Byron adopted the simple and normal style, he would not have been the distinguished dark romantic poet he is.

Despite the complicated gender and sexual setup of Kaled's character, s/he remains actual and convincing to readers in much the same way as s/he is to Byron himself, who as a pansexual/polysexual had already experienced or enacted such forked and queer transgressions throughout his life and travels.

\section{Transvestism}

A gothic narrative poem, Lara is a masquerade of the dynamic maneuvering of gender performances. Possessing queer psycho-sexual traits, Kaled is a transvestite, androgynous and pandrogynous. The relationship between these three manifestations of sexual deviancies is subtle and identifiable through Kaled's intricate and artistic performance of normative gender transgression.

Terry Castle in The Female Thermometer explicates the importance of masquerade in defying and transgressing the eighteenth and the nineteenth century culture by destabilizing/undermining the identity of gender:

For the masquerade indeed provided the eighteenth century with a novel imagery of sexual possibility. Its manifold displacements and enigmas... register[ed] for the first time that ironic resistance to the purely instinctual which has increasingly come to characterize the erotic life of the West since the eighteenth century. In particular, in its stylized assault on gender boundaries, the masquerade played an interesting part in the creation of the modern "polymorphous" subject-perverse by definition, sexually ambidextrous, and potentially unlimited in the range of its desires. (84)

Reversing gender roles and overstepping gender boundaries are common romantic themes that mark the individuality of the poet. While studying at Harrow school, Byron had been engaged in same sex liaisons: Rolf Lessenich speaks about Byron's romantic affairs with male teens: "Byron's... choice of 15-to-17-year-old male lovers: John Edleston was a Trinity choir boy, John Cowell the son of a merchant, Robert Rushton the son of one of his tenants, Eustathios Georgiou and Nicolo Giraud devoted servant boys, and his last love, Loukas Chalandritsanos, was the son of an impoverished Peloponnesian family" (142). Furthermore, Harriet Stowe hints at a homosexual relationship between Byron and his male friends and claims that Byron "led captive Moore and Murray by being beautiful" and that he "first insulted Walter Scott, and then witched his heart by ingenious confessions and poetic compliments; he took Wilson's heart by flattering messages" (85-86). Moreover, she contends that Thomas Moore "was as much bewitched by him [Byron] as ever man has been by woman; and therefore to him, at last, the task of editing Byron's memoirs was given" (99).

Through the narrative technique of transtexuality, Byron wittingly keeps on switching Kaled from one gender to another to securely justify same-sex cravings. In this way, Byron protects himself from further scandals. Nowell Marshall notes that "transtextuality occurs when authors transition characters from one sex to another to safely evoke same-sex desire within their work" (27). Thus, the transgender body of Kaled exonerates Byron from homosexual accusations. To this effect, Byron's elaboration of Lara as an Oriental tale indicates his open mindedness and projects ideas of homosexuality on the Orient which, at the time, was a foil to the rational Occident deemed a homophobic prejudiced culture where homosexuality, which counters religion by denying the hope of reproduction, was prohibited and threatened by capital punishment. Not to mention that Oscar Wilde, an Irish Victorian poet and playwright, was tried for sodomy in 1895 and jailed for two years.

One way of re-arranging genders is through crossdressing: an act suggestive of one who engages in homosexual/homoerotic performativity. Such transvestites achieve transgressive sexual relations and freely cross cultural/social boundaries similarly as the disguised Caroline Lamb did to gain access to Byron's bedroom. In the same fashion, Kaled, through the masquerade motif, disguises in order to maintain intimate closeness to Count Lara. It seems that Byron was in reality attracted to women with untraditional gender dispositions, those who unashamedly carry themselves as men.

Such cross-dressing, does not only function as a means to reach freedom, attain power and satisfy inner 
desires, but it also threatens a rigid patriarchal milieu in which a female voice is suppressed. Deviating from the conventional norms of sexuality and gender by adopting masculine apparel, Kaled is now enabled to freely play the new role with particular relish and revel in all that women have been restricted from. Through Kaled's performative act, Byron achieves social independence and gives reign to his male homosexual desires/emotions (to seduce and be seduced). As a disguised female, Kaled acquires the freedom to choose a suitable identity or a proper gender performance to pursue his/her desire/love. As such, "disguise provided a much-desired emotional access to new sensual and ethical realms" (Castle 83).

When Byron voyaged to the Levant, he discerned that sodomy was prevalent in Turkey. Hence, one probable reason why Byron delineates Kaled as an Oriental character is to justify signs of sodomy in the poem. Kaled is described by Byron as an enigmatic and exotic young man overtly engaged in satiated homoerotic adventures under "his native sun": "Light was his form, and darkly delicate/ That brow whereon his native sun had sate," (XXVI). There is also an aura of mystery and privacy around the bond between Kaled and Lara since the former's commitment to his/her lord appears questionable: "Silent** as him he served, his faith appears" (XXV). As for Lara, his silence also arouses suspicion: "His silence formed a theme for others' prate-" (XVIII). Moreover, Lara, who "stood a stranger in this breathing world,/ An erring spirit from another hurl'd;/ A thing of dark imaginings..." (11. 315-17), effectively brings to mind Foucault's statement in The History of Sexuality that, "it is up to us to extract the truth of sex, since this truth is beyond its grasp; it is up to sex to tell us our truth, since sex is what holds it in darkness" (1: 77). As such, Lara is hiding a dark sexual secret in his relationship with Kaled.

Added to this, it is unclear why Lara is chronically awake while others are asleep and why his mansion is not open for visitors. In these lines lie the hint of a timid sign of a silent same sex love and unmentionable homosocial libidinal male desire; Byron, the narrator, admits that Kaled loves Lara:

If aught he loved, 't was Lara; but was shown

His faith in reverence and in deeds alone;

In mute attention; and his care, which guess'd

Each wish, fulfill'd it ere the tongue express'd (XXVII).

Kaled is capable of interpreting or understanding Lara without resorting to speech or language and is aware of all the latter's unspoken wishes. Homosexual intimacy between them is indirectly discerned in the above lines. Particularly, their silence reveals a lot about their relationship and obviously exposes Byron's fear to advertise his homosexual inclinations.

Together with Byron's affinity with the identifiable pederasty among the Greeks is his apparent interest in oriental hemophilic cultures, mainly in Ottoman pederasty. Gerard Cohen-Vrignaud interprets Kaled as an emblem of the Romantic preoccupation with Oriental sexuality, specifically page lads called icoglans, who served "not only as attendants but also as sexual servants" (9). Kaled is accurately presented as a page boy; maleness is his biological sex: "His soul in youth was haughty, but his sins/ No more than pleasure from the stripling wins;" (IV). Even more so is the use of the adjective "stripling" signifying maturation from boyhood to manhood which also harbors homosexual insinuations:

And Lara call'd his page, and went his way -

Well could that stripling word or sign obey:

His only follower from those climes afar,

Where the soul glows beneath a brighter star;

For Lara left the shore from whence he sprung,

In duty patient, and sedate though young; (XXV)

According to Cohen-Vrignaud, the word "stripling" attributed to men emphasizes:

Kaled's transitional phase between boy and man and implies the sort of physical appreciation that may be casual or more erotically probing (as the root "strip" hints). Moreover, "duty patient" suggests not only the "duty" of domestic service but also the particular kind of "patience" often associated with the "pathic" partner in male/male penetration (an allusion also encoded in the term "sedate," whose root in the Latin verb for sitting emphasizes Kaled's "seat." (19)

Kaled decides to follow Lara willingly as a page regardless of whether s/he is needed or not; s/he is masculinized to follow his/her lover and to be rendered whole by their love. Towards the end of the tale, when Kaled reveals his/her femininity, Byron describes Kaled's intense feelings for Lara, as the man "... he loved" (XXI).

As for the disguise or masquerade motif, it allows fluidity and mobility between the appearance and attitude of the individual in disguise. In this way, Kaled, as a boy, could easily be around Lara and perform like a male. However, in that state of camouflage, s/he goes as far as killing Ezzeline, 
her lover's potential killer. Thus, the masculine apparel empowered him/her to perform as a male. Undoubtedly, the homoerotic bond between Lara and his page is more serious than the other sensual affiliations Lara was involved in when he was in foreign lands. Now that Lara is in his homeland (British Isles), his homosexual lustful passions will be controlled by law: "Within that land was many a malcontent,/.../ That soil full many a wringing despot saw,/ Who work'd his wantonness in form of law;" (VIII).

Moreover, it is obvious that Kaled is the sole character who is informed about Lara's past secrets, and their silent way of communicating with each other is striking and typical of how lovers communicate. Before the fight with Ezzelin, Kaled promises and comforts his master, stating that $\mathrm{s} /$ he will stay loyal with only death to separate them. This is effectively portrayed in the striking, sad image of a faithful and everlasting commitment at the end of the battle to attain political liberty. In this scene, an "unwonted" and mysterious affinity is exposed between Kaled and Lara who:

... turn'd his eye on Kaled, ever near,

And still too faithful to betray one fear;

Perchance 't was but the moon's dim twilight threw

Along his aspect an unwonted hue...

This Lara mark'd, and laid his hand on his:

It trembled not in such an hour as this;

His lip was silent, scarcely beat his heart,

His eye alone proclaim'd, "We will not part!

Thy band may perish, or thy friends may flee,

Farewell to life, but not adieu to thee!" (XIV)

The intimate physical touching of the hand as "his hand on his" tells a lot about being "ever near" and an ambience of homosexual sensuality is under display. It can be deduced that love sentiments are reciprocated by both sexes, whether same or different.

Kaled's actions and appearance/disguise are propelled by love and desire. As a Byronic hero, his doubleidentity closely reveals both forms of desperation: the physical and performative. In a sense, he expresses:

... haughtiness in all he did...

His zeal, though more than that of servile hands,

In act alone obeys, his air commands;

As if 'twas Lara's less than his desire

That thus he served, but surely not for hire.

Slight were the tasks enjoin'd him by his lord,

To hold the stirrup, or to bear the sword;

To tune his lute, or, if he will'd it more, (XXVII)
Again, the relationship between the textual and sexual implications is considerably suggestive of a homosexual relationship; it is thus love that prompts Kaled to offer his services to Lara. Seduced by/and into masculinity, Kaled remarkably divulges male desires: "his desire" towards Lara. In fact, the "slight...tasks" that Kaled has to execute for Lara are more than tending to the stirrup, the sword, or the lute; it all depends on what Lara desires. Hence, if Lara desires more, Kaled willingly obliges. What they "share between themselves" is a dark secret of homoeroticism that Byron does not want to lay bare:

They seem'd even then - that twain - unto the last To half forget the present in the past;

To share between themselves some separate fate,

Whose darkness none beside should penetrate. (XVIII)

Same-sex desire reciprocated between Kaled and Lara is further portrayed towards the end of the tale when Lara rejects "the absolving cross" and refuses to repent (similar to what the Giaour did) before his demise in order to save his sinning/errant soul. Both Lara and the Giaour shun remorse, avoiding their religious duties since they are rebellious heathens. Strangely enough, both Lara and Kaled repulse such a "sacred gift," knowing that their souls are doomed and unforgivable since they elect to deny their faith by committing antireligious taboo acts:

For when one near display'd the absolving cross,

And proffer'd to his touch the holy bead,

Of which his parting soul might own the need,

He look'd upon it with an eye profane,

And smiled- Heaven pardon! If ' $t$ were with disdain:

And Kaled, though he spoke not, nor withdrew

From Lara's face his fix'd despairing view,

With brow repulsive, and with gesture swift,

Flung back the hand which held the sacred gift,

As if such but disturb'd the expiring man,

Nor seem'd to know his life but then began,

That life of Immortality secure

To none, save them whose faith in Christ is sure.

(XIX)

By subverting gender stereotyping, Kaled establishes a new independent identity as a courageous powerful woman who assumes the initiative to chase her love regardless of the obstacles. She establishes de Beauvoir's notion that identity is socially constructed when in reality, any biological gender should have the right and the choice to be whoever s/he desires. As the tale insinuates, women are 
capable of shaking the cultural order, attaining their ambitions in a male-controlled environment. Through the cross-dressing technique, Byron explores the potential of females to be as brave and independent as men; his use of disguise highlights the notion that apparel is a performative act designed to determine gender. Furthermore, crossdressing is a double edged sword since it ironically both suppresses and divulges Byron's homoerotic desires.

\section{Androgyny}

Androgyny has a long history; it has deep roots in Greek mythology that presented many samples of androgynous characters such as the wise blind Tiresias. The word "androgyny" falls within the realm of sexual behavior and gender identity; it is defined by the encyclopedia Britannica as a "condition in which characteristics of both sexes are clearly expressed in a single individual." Psychologically speaking, androgynous people are characterized by a powerful disposition, being simultaneously tender and resilient. The specific biological term of androgynous humans, possessing masculine and feminine traits, is "hermaphrodite." Used to express the link between an individual's physical outlook, attitude, sex and sexuality, the adjective "androgynous" is synonymous to "dual gendered" and "hermaphroditic." Due to the fact that an androgynous character is transgressively gendered with combined masculine and feminine characteristics, such character is inclined towards bisexual performativity.

Moreover, androgyny has been a romantic attraction and a psychological interest as expressed by Samuel Taylor Coleridge in 1832, "The truth is, a great mind must be androgynous" insinuating that a creative poet should write from different perspectives: male and female. Similarly, Sigmund Freud posits, "No healthy person, it appears, can fail to make some addition that might be called perverse to the normal sexual aim" (74). Human sexuality, according to Freud, is naturally transgressive; hence, encroaching representations of sexual liaisons are natural and healthy. This foregrounds the concept of a character's heterogeneous and ambisexual nature that Byron strongly advocates and creatively demonstrates in Lara.

In literature, androgyny is identified "as a shift across a line-segment with absolute male and absolute female serving as the conceptual endpoints, with the androgyny hovering somewhere in the middle of the spectrum" (Lofdahl 26). Byron produces such characters with multiple juxtaposing identities that challenge normative gender paradigm. In this mode, he manipulates the use of his androgynous characters to the extent that the perception of the effeminate male and the masculine female in Kaled is rendered convoluted. Cross-dressing adds ambiguity to such a character that becomes both a male and female, performing femininity and masculinity simultaneously.

Throughout the tale, Kaled allures readers with masculine and feminine performances. Choosing to live in a world ruled by males, Kaled resorts to cross-dressing in order to be socially accepted. However, this character's feminine instinct sometimes reveals itself in a mystifying and enigmatic manner, thereby satisfying her/his feminine/masculine desires. In this case, the tale undeniably encourages the seduced to seduce; thus, readers gain pleasure from Kaled's multifaceted performative acts within the poem. That is, beguiled by Lara, Kaled in return captivates readers by undertaking a bisexual nature aimed at attaining unconstrained access to unrestricted pleasure and gratification. In this respect, the illicit sexual make-up of such a bisexual character makes pleasure more enchanting. Notably, Kaled bears the resemblance to the philosophical and erogenous creation of the Sadian (in reference of the French philosopher, Marquis de Sade) sexual predator since this disguised page focuses on his/her insatiable individual pleasure, regardless of what gender variation s/he undertakes.

Uprooting herself from her community, Kaled willingly sacrifices her identity for the sake of love and passion. She intentionally changes her gender and selflessly devotes her life to staying close to Lara and tending him. As such, Kaled's performative acts indicate that $\mathrm{s} / \mathrm{h}$ masters the art of masculinizing and feminizing his/her passions. Even though dressed as a page, Kaled instinctively resorts to her original gender and performs the role of a caring mother. To illustrate, when Lara starts having disquieting nightmares and fainting as a result, Kaled rushes as an affectionate mother bending over her terrified youngster to soothe him using strange unfathomable tunes and language solely both of them comprehend. Such display of sentiments produces the desired affectionate response as, “... Lara heeds those tones that gently seem/ To soothe away the horrors of his dream-" $(\mathrm{XV})$. The effect of such an affectionate language and its effect arise out of a mutual understanding between Lara and Kaled. On the other hand, this feminine act could harbor homosexual connotations: is this a homoerotic language evoking a homoerotic desire that soothes the alarmed Lara? As to the bending posture, is it Kaled's homoerotic dream or a homosexual act performed by this page? In a sense, both the voice and posture indicate Kaled's ability to perform in a heterogeneous manner. Another reference towards the end of the tale further harbors this point; "he loved so well" (XXI) 
suggests that through the usage of the adverb "well" that the bisexual Kaled performs extremely well in various love acts. As a transvestite male page and as a female, Kaled expresses unquenchable sexual cravings not too different from Byron's.

Evidence of Byron's bisexual tendencies is found in his own admissions of preference for dark features in both genders. In his letters and journals, he describes John Eldeston, one of his lovers, as, "He is nearly my height, very thin, very fair complexion, dark eyes, and light locks" (BLJ 94). Furthermore, Byron admires similar dark features in females, for instance, Mary Duff, whom he delineates as "very pretty ... the perfect image of her in my memory-her brown, dark hair, and hazel eyes" (BLJ 29). To strengthen the depiction of Byron as bisexual, one notes his description of Kaled's dark complexion coincides with his opinion of Caroline Lamb when he states, "I was much tempted;-C** looked so Turkish with her red turban, and her regular dark and clear features. Not that she and $I$ ever were, or could be, anything; but I love any aspect that reminds me of the "children of the sun" (BLJ 238). Surprisingly, Kaled is construed in an almost identical manner as "darkly" due to his "native sun" (XXVI) and Byron also refers to him as "that dark page" (XVII).

Interestingly, Kaled is a typical representation of what Alexander Pope describes in his "Epistle to a Lady" - a "softer Man." Byron knits such a bisexual character as he 'mans' Kaled. Even though Kaled's physical appearance resembles that of a man, his/her attitude as outlined above is feminine. The androgynous Kaled mirrors Byron's sexual identity and psychosexual behavior, allowing the poet to witness his own bisexuality through the gender transgressive character of such a page. In fact, Byron projects the image of Kaled to reflect his bisexuality through his "softer man" disposition. One of Byron's contemporaries describes his effeminate features, appearance and attitude: "I once met Lord Byron before he was known, before he travelled. Such a fantastic and effeminate thing I never saw. It was all rings and curls and lace. I was ashamed to speak to him; he looked more like a girl than a boy;" it is obvious that Byron has no qualms overtly exposing his feminine inclinations when he defends his unusual act of curling his hair: "I am as vain of my curls as a girl of sixteen" (qtd. in Elfenbein 209). Undoubtedly, Byron was well aware of (and flaunted) his feminine identity.

Facing the feminine version of himself, Byron dissolves differentiation and transcends normative sexual identity. In other words, sexual identification and gender disperse to refashion a unique androgynous/bisexual identity.
According to Stowe in Lady Byron Vindicated, Byron's biographer Moore was "as much bewitched by him as ever man has been by woman" (62). In her opinion, by being a male seducer, Byron acts more as a female than as a male. Not only does he master the art of homosexual seduction, but also that of heterosexual/bisexual seduction; Stowe remarks, "Mrs. Leigh was no more seduced than all the rest of the world" (223). In addition, David Jones mentions one woman's sensuous response to Byron's poetry to establish his seductive power:

'Why, did my breast with rapture glow? Thy talents to admire, why, as I read, my bosom felt? Enthusiastic fire.' These readers' descriptions of their physical reaction to Byron's work - the letters are filled with fluttering hearts, fiery bosoms and wild tumults -show the success of Byron's image as a seductive bad- boy. (73)

As Byron delineates the questionable character of Kaled, the poet oscillates between male homosexuality and bisexuality. In spite of this lad's "tender frame," he is the opposite of what $\mathrm{s} /$ he appears. With the combined qualities of a fierce male and a tender female, Kaled becomes a softer man, allowing Byron to inform readers that normative gender has no grounds in tragic/sentimental love narratives, and gender boundaries are flexible/open-ended and do not entail a fixed truth:

More wild and high than woman's eye betrays,

A latent fierceness that far more became

His fiery climate than his tender frame:

True, in his words it broke not from his breast,

But from his aspect might be more than guess'd. (XXVII)

Despite the fact that Kaled performs the roles of both subject and object, he is neither a prototypical passive female nor an archetypal subservient page. Through his/her manly performance, he carries out the homicide act and fearlessly disposes of the corpse in the river. Moreover, as a male page, he performed in an overconfident manner: "there was haughtiness in all he did," (XXVII). The peripheral line between the feminine and masculine is not rigid, but fluctuates, making the character so malleable that s/he looks both homosexual and heterosexual/bisexual concurrently. Displaying a genuine antithetical/mixed version of human nature by performing male and female gender, Kaled mirrors Byron's bisexuality, more specifically his feminine self. Every time Kaled switches to a different gender, s/he 
undergoes an internal quest to discover his/her own double sexual/gender inclinations. The opacity of homosexuality and heterosexuality/bisexuality between Lara and Kaled addresses various audiences with various sexual inclinations and tastes. In brief, such a Byronic hero with contradictory, ambiguous traits is the closest reflection of human nature. Accordingly, Claudia Moscovici in Gender and Citizenship admits:

Today, more than, ever, we appear to live in an androgynous age. Women vote and hold office while also being maternal. Men are masculine yet sensitive. What seemed to be an impossible combination of masculine and feminine characteristics has become, through historical and dialectical development, simply a new definition of sexual identity. (111)

The gender equivocal character, Kaled, is a masculinized female cross-dresser who trespasses the laws of feminine stereotypes for the sake of pure love. Since Byron's contention is "to effeminize patriarchal rule thereby castrating the established ideology," (Lofdahl 32) he empowers the phallic female, highlighting her sovereignty to become the gender she craves. Subsequently, Kaled's sexual freedom and free will permits him/her to transgress desires as she masculinizes and feminizes her passions. In this case, love can only be true if it entails liberty, and this is Byron's recommendation through transgression. Through bodily transformation and gender crossing, Kaled gives reign to his/her desires and becomes a powerful sexually democratic being unrestrictedly roving in a manly world without the oppression of patriarchy.

\section{Pandrogyny}

Normative heterosexuality is somehow abandoned in Lara where blurred traces of Byronic 'homosociality' and bisexuality culminate in the poetic creativity of a third gender trope: pandrogyny. According to Urban dictionary, pandrogyny is "the conscious embracing of elements from so many sexualities/sexual orientations." Since pandrogyny, unlike androgyny, highlights the similarities between opposite genders rather than the differences, distinctive gender roles melt and totally disintegrate to create an original identity; a new gender-neutral/gender ambiguous being, called the third being, is born. Such a neutral individual resembles Irigaray's notion of a female whom she believes possesses invisible sex organs lacking a definite shape; Irigaray explains that a woman's "sexual organ ... is not one organ" and "is counted as none" (26). Such being the case, this transformed/transcendent character is liberated from the restraints of identity, sex and gender. In fact, it is Genesis POrridge, an English performance artist, who coined the term pandrogyny in his remark:

We, as magickal, creative, soul builders are inherently empowered to truly decide which physical, sexual, or inspirationally creative components to include or discard in order to build whatever identity or biological container we chose, no matter how bizarre or physically unlikely, or how socially uncomfortable or disliked. (qtd. in Barnsley 46-47).

The previous androgynous phase functions as a transition that leads to the third or intermediate sex indicating Byron's sexual tendencies. Since his gender tension is unresolved through androgyny, Byron discovers a new artistic status and a more suitable outlet to reconcile gendered polarities, which is pandrogyny. Ultimately, this narrative poem is the prism through which he reflects the gender discourse conflict that haunted him lengthily. Foregrounding an innovative way to read his character's human body and understand the atypical desires of his own, Byron formalizes an exotic cultural phenomenon strange enough to ignite his reader's sexual curiosity.

In her theory of "écriture feminine," Helene Cixous' concept of "the other bisexuality," which she particularizes as the "location within oneself of the presence of both sexes" advertises the notion of embracing the other in oneself. Similarly, Byron moves a step further, celebrating the spiritual and physical merging with 'the other' so that his hero and heroine's identity and gender become unstable and neutral. This is Byron's radical, unconventional concept of the third sex in which the subject and the object are enfolded physically and spiritually in one body and soul. In this sense, Marshall recognizes that "Byron's treatment of his transgender character is more progressive than other male gothic authors" (40). In the process of describing the evolvement of Kaled's performance from one gender to a new version of it, Byron transitions Kaled and skillfully tailors a queer transgender image in which Kaled becomes the reflection of Lara. This movement from "another sex" to third sex is what contributes in maturing Kaled. The third gender, instead of being depicted as a sexual myth, is employed by Byron as a sexual truth. The creation of a third being is a sublime tactic. It is the aftermath of Byron's sexual imagination, a creation who is more than an effeminate page or effeminate sodomite, simply another transformed gender. 
Initially, as a young male or female, Kaled's feminine traits merge with the masculine ones, so that $\mathrm{s} / \mathrm{he}$ is smoothly able to switch roles from time to time. Notice for example, the white hands and soft cheeks, unmarked by hard labor, that depict an aristocratic adolescent female to highlight her feminine status, while at the same time, the fierce, wild gaze renders this character masculine. A destabilized performative character par excellence, Kaled flaunts the captivating beauty and split personalities and experiences of the third sex:

Of higher birth he seem'd, and better days,

Nor mark of vulgar toil that hand betrays,

So femininely white it might bespeak

Another sex, when match'd with that smooth cheek,

But for his garb, and something in his gaze,

More wild and high than woman's eye betrays;

A latent fierceness that far more became

His fiery climate than his tender frame:

True, in his words it broke not from his breast,

But from his aspect might be more than guessed.

\section{(XXVII)}

If this character's external appearance betrays his/her real identity, and if this character is neither a lad nor a lass, who could s/he be? In the last line, Byron offers a clue, inviting his readers to deduce his/her gender, as he says, Kaled "might be more than guessed" with a gender that is "halfconceal'd" (XXI). In other words, this character is more than a female and more than a male; it is an "another sex" that Byron hints at: a progressive one that evolves as the tale unfolds and assumes the dramatic form of a third gender in the tale's tragic denouement.

Consequently, Lara and Kaled are transformed into a believable sexual truth- a third gender that reflects a united neutral character, neither a typical male nor a typical female, but a combination of both in one ambiguous character: the trope of the third being is rendered a transparent, magic mirror through which two lovers see an animate replica of each other. Hence, Kaled becomes a similar Lara: both are of the same gender, being fluent in the same foreign language, communicating without words, wearing similar garments and sharing the same passions/desires.

Interestingly enough, as Kaled removes the masculine mask, and Byron refers to her using an object pronoun "her" for the first time, she reveals no signs whatsoever of sexual appeal or potency, as if she were in reality a male not embarrassed to reveal his naked breasts. Stripped of any opportunity to display her sexuality, she,
Kaled, now senses no need "to revive those lifeless breasts." As one who has always performed as a male, the exposure of breasts becomes normal; she willingly abandons her femininity and brazenly exposes her breasts. This interchangeability between the man and woman status renders gender both fluid and destabilized. Despite the fact that Kaled is unsexed towards the end of the tale, she maintains her masculine Arabic name until the end of the poem. With the death of Lara, her sexual craving as well her femininity becomes ineffective and infertile:

The secret long and yet but half conceal'd; In baring to revive that lifeless breast, Its grief seem'd ended, but the sex confess'd; And life return'd, and Kaled felt no shame What now to her was Womanhood or Fame? (XXI)

Surprisingly, after Lara's demise, Kaled incarnates Lara's soul and identity since the supposedly feminine figure, Kaled, becomes the image of Lara himself and starts imitating him. Once again Kaled is re-masculinized, thus, resacrificing her identity for the sake of an eternal/immortal transgressive union to become one body and soul with Lara:

And she would sit beneath the very tree,

Where lay his drooping head upon her knee:

And in that posture where she saw him fall,

His words, his looks, his dying grasp recall; (XXV)

"[I]n that posture" sits Kaled and starts reiterating Lara's words. In other words, Kaled imitates Lara to the extent that he is transformed into Lara himself especially that she imagines having a conversation with him: "Herself would question, and for him reply;" (XXV). Interestingly, this development is foreshadowed at the beginning of the poem: "And in that tongue which seem'd his own replied," (XIV). It is as if Lara and Kaled's "lips speak together" (205) to use an Irigarayan expression. Both the count and the page not only master the same language but share the same thoughts and responses as though they were one person. This similar image is depicted by Irigaray describing how lovers mysteriously speak several languages, yet fathom each other perfectly: "Between our lips, yours and mine, several voices, several ways of speaking resound endlessly, back and forth" (209). In the same fashion, Lara and Kaled's unity through the trope of a common foreign language minimizes gender differences, solidifies their eternal love, brings them closer and mends their desires.

As Lara and Kaled poetically and corporally possess the same self and the same "tongue," Manfred and Astarte 
figuratively and carnally endowed with the same heart merging them into one being. To the Chamois Hunter, Manfred once confessed, "When we were in our youth, and had one heart" (I; ii); as if Manfred and Astarte, his sister and lover, used to share his heart. The same concept is duplicated when Manfred describes Astarte as a mirror reflecting himself; they are one person, possessing one mirrored identity. The only difference between them is that she is prettier:

She was like me in lineaments; her eyes, Her hair, her features, all, to the very tone Even of her voice, they said were like to mine...

She had the same lone thoughts and wanderings, The quest of hidden knowledge, and a mind To comprehend the universe... (Manfred II: ii)

Another telltale image of Lara and Kaled mirroring each other and of the Byronic creativity of redesigning gender is portrayed at the end when Lara,

... turn'd his eye on Kaled, ever near,

And still too faithful to betray one fear;

Perchance 't was but the moon's dim twilight threw

Along his aspect an unwonted hue...

This Lara mark'd, and laid his hand on his:

It trembled not in such an hour as this;

His lip was silent, scarcely beat his heart,

His eye alone proclaim'd -

"We will not part!... (XIV)

Lovers reach the peak of their commitment as the mirror image intensifies their amorous bond, and they become physically and spiritually unified. This merging is a phenomenal feature of the third gender. One notices how the Byronic hero's identity is made indistinct, as it is not clear whose hand is on whom. As body parts are dissolved in one sexed body, this haziness is further intensified when other body parts, such as "lip", "heart" and "eye" are portrayed independently. It could be read as if "we" cannot be divided into "parts" since love molds us into one entity with lovers possessing one unified identity. Another inference of the ambiguous 'hand' image occurs when Lara was passing away:

But gasping heaved the breath that Lara drew,...

His limbs stretch'd fluttering, and his head droop'd o'er...

He press'd the hand he held upon his heart It beats no more, but Kaled will not part
With the cold grasp... (XX)

The pressing of "the hand he held upon his heart" is substantially vague; it is unconfirmed whose hand and whose heart it is. This echoes Irigaray's description of true lovers who experience inseparability as each lover "is never separable from the other" (209). In the same sense, Irigaray further describes such a harmonious state of an intimate contact saying: "[y]ou become whatever touches you" (210). The lovers' personal identity in the above lines is marred to the point that their performance is mutually harmonized. Cohen-Vrignaud elucidates that "He press'd the hand he held upon his heart" [t]he heavy alliteration of hs... sonically mimics not only the "heaving" breath of a dying man but also the "gasping" of his grieving companion" (21). It is as if both Lara and Kaled are breathing their last since it is unclear who is "heaving" and who is "gasping." For this reason, touching at this stage is critical since it is a testimony that a fading lover feels 'alive' by the animate touch of 'the other', as Irigaray explains: 'I/you touch you/me, that's quite enough for us to feel alive" (209). Ultimately, when the heart "beats no more," (XX) the implication is that both are dead: one physically and the other emotionally. Since lovers are inseparable and undistinguishable: what befalls one, automatically affects the other. Interestingly, what these lovers experience is analogous to the sentiments Irigaray describes in This Sex Which Is Not One:

Already, I carry you with me everywhere.... I do not contain you or retain you in my stomach, my arms, my head. Nor in my memory, my mind, my language. You are there, like my skin. With you I am certain of existing beyond all appearances, all disguises, all designations. I am assured of living because you are duplicating my life. Which doesn't mean that you give me yours, or subordinate it to mine... How can I say it differently? ... We live by twos beyond all mirages, images, mirrors...

Although we can dissimulate perfectly within their economy, we relate to one another without simulacrum. Our resemblance does without semblances: for in our bodies, we are already the same. Touch yourself, touch me, you'll 'see.' (216)

It is as if Lara touches himself through Kaled and vice versa in order for both to be revived since they are united in one body. In this respect, Irigaray reiterates, "I'm touching you, that's quite enough to let me know that you are my body" (208). 
Speaking in terms of gender unity, the effeminate sodomite Kaled mirrors Lord Lara, allowing each self to look profoundly into the other's identity to conceive what is within the self. Consequently, both acquire a new self and attain at the end a unified pandrogynous gender in which the masculine and feminine polarities of these lovers are absent. Ultimately, it is the synthesizing voice of love that transgresses gender and traverses the harsh obstacles of sexual codes.

The mirror motif indicates a switch or a twist in gendered roles and the doubling of the Byronic hero who faces a female copy of himself. An Irigarayan term "a living mirror" best fits these lovers since Kaled becomes Lara's double; s/he is read as Lara's idealized masculinized/feminized self-projection. It is ideal when two beings become gender neutral and equal in their erotic desires and perform like intertwined twins. Such a condition is adequately expressed by David Hartley who states that "if beings of the same nature . . . be exposed for an indefinite time to the same impressions and associations, all their particular differences will, at last, be overruled, and they will become perfectly similar, or even equal" (68).

Another striking, matchless textual exposition of the third sex gender is noticeable at the end of the tale: "They were not common links, that form'd the chain/ That bound to Lara Kaled's heart and brain;/ But that wild tale she brook'd not to unfold," (XXII). Interestingly, Byron suggests here an idiosyncratic marriage of philosophical beliefs with corporal desires, hinting that pleasure, as an outcome of love and passion, is no longer satisfied merely physically; pleasure is intellectual. As such, the visceral and cerebral combination of "Lara Kaled" in one "chain" is poetically "not common" and the image of such a conjoined twin having one "heart and brain" is remarkably suggestive of a distinctive asexual representation of a realistic biological epicene, especially since the male has a female's name, and the female is using a man's. In the end, both names reveal the extent to which the lover's indeterminate sexes are entwined.

The third gender as a literary concept is expressed in the manner in which gender associations undergo evolution. Through it, Byron delivers a message that love can transcend gender categorization, promoting the belief that a variety of sex liaisons and desires are normal. In Don Juan, Byron confesses that he spurs enchainment to the rigid shell of gender categorization because, he actually believes in an "infinite variety" of heterogeneous bonds between humans, passions cannot be restricted to fixed cultural norms:

I perch upon an humbler promontory,
Amidst life's infinite variety...

... whene'er I have express'd

Opinions two, which at first sight may look

Twin opposites, the second is the best.

Perhaps I have a third too in a nook,

Or none at all-which seems a sorry jest;

But if a writer should be quite consistent,

How could he possibly show things existent?

\section{(LXXXVII)}

Such myriad variations of sexual mores are what Byron is in favor of and what his characters are exposed to in order to pleasantly gratify their inner desires. In the above quote, Byron hints at a third opinion, third sex or no sex, a sexless being he believes exists. As a revolutionary poet, Byron cannot be restricted to stagnant gender structures; he challenges natural law and gender opposition, promoting a new liberalized gender harmonizing with the wide scope of life's diversities. This is a unique narrative scheme intriguing the audience; it elicits an endeavor at interpreting and reevaluating the nature of intimacy between Lara and Kaled that Byron attempts to keep obscure. If one queries the reason why Byron portrays such a pandrogynous character, the answer is found in Jung's archetypal image: Kaled is Lara's "anima," his inner female side. In other words, she is the woman in him, his physical and spiritual double; she completes him and is unable to exist without him.

Crucially, Byron's interest in epicene is behind his portrayal of an androgynous, pandrogynous character. As a visionary poet, he ingeniously expresses the hidden desires and imaginings of people in the present age. Unexpectedly, the uncommon becomes common with Byron's artistry. Nowadays, transgender people appear to be on the increase in the way they submit sex reassignment surgery. Byron, ahead of his time, expressed such an inherent desire in his poems and most explicitly in Lara, in which he advances the third sex theory, situating the human body within a futuristic anthropological paradigm. Thus, Byron futuristically envisioned the possibility for a mortal being to transcend and evolve into a third entity. In this respect, a reader wonders whether there will eventually exist a new species of humanity!

In "sexual otherwise," Derrida's notion of unrestricted/infinite sexuality or "polysexuality" is expressed as the dream of reaching a state of no sexual difference:

....a relationship to the other where the code of sexual marks would no longer be discriminating.... The relationship... would be sexual otherwise: 
beyond the binary difference that governs the decorum of all codes, beyond the opposition feminine-masculine, beyond bi-sexuality as well, beyond homosexuality and heterosexuality, which come to the same thing. (455)

Derrida's "sexual otherwise" is akin to Byron's epicene. It establishes that Byron is essentially a pioneer in his vivid and expressive portrayal of a reconstructed performative gender evolving towards the third sex. Furthermore, Byron's depiction of epicene resembles one essential feature of the Sadian sexual predator: gender neutrality.

\section{CONCLUSION}

A libertine tale overtly displaying atypical, questionable desires, Lara paves the way for dissident readings of a metaphysical poetic text in which Byron simultaneously exposes and obscures the murky confidences of his sexual self. Without doubt, he is displaying a performance of himself via the character production of Kaled.

Gender is constructed performatively throughout Lara. A multi-gendered Byronic hero, Kaled undergoes portrayals that challenge heteronormativity: sexual and social decorum. Byron's multiple representations of anti-social sexuality through gender fluidity have been examined through the lens of Butler's gender performance and that of Irigaray's animated mirror motif. By concealing his homosociality and his deviant sexual desires which Andrew Elfenbein accurately describes as "omnivorous," (209) Byron postulates a novel gender, a third gender with an androgynous/pandrogynous inclination. The poet also attempts to resolve the divisional gender crisis by deconstructing gender differences through degendering Kaled's body and conduct. Idiosyncratically, Kaled acts as if $\mathrm{s} / \mathrm{he}$ is all genders; nevertheless, this character also performs similar to a genderless individual, unveiling Byron's philosophy that since the body can fluctuate, then gender binary is no longer a significant manner.

Surprisingly, Byron subverts conventional gender identity in Lara and intentionally uses cross-dressing as a pretext to indirectly advertise sexual democracy. Through his unrelenting exploration of gender and experimenting with several styles of femininity and masculinity, he proposes a third gender, paving the way for a further controversial/philosophical debate on sexual freedom. In reality, Byron proves to be an uncommon poet of human nature in the manner he envisions sexuality. In a way, as one who understands both sexes, he implements a transgressive strategy to dismantle gender differences and furnish women a voice.

Renowned for his genuine Romantic representation of passion in his poems, Byron also reveals sexual mores and transgressions that mirror the anxiety of the modern era. This is what Foucault clarifies when he states that "[w]hat is peculiar to modern societies... is not that they consigned sex to a shadow existence, but that they dedicated themselves to speaking of it ad infinitum, while exploiting it as the secret" (1:35).

To conclude, the erotic plethora of transgressive desires in Byron's works is what draws many readers to savor the poetry of a mad, bad, dangerous poet who has artistically and unequally portrayed, in Foucauldian terms, "aesthetics of existence." The choice of such an Oriental tale, Lara, to highlight sexual transgression could lend itself to further enticing imaginings in the realms of sexual relations in Byronic oeuvres such as Don Juan, Manfred, The Corsair, The Bride of Abydos, The Giaour and Parisina.

\section{REFERENCES}

[1] Barnsley, Jennie. Grounding Theology in Quotidian Experiences of Complex Gender: A Feminist Approach. Diss. University of Birmingham Research Archive, 2013. Web.

[2] Butler, Judith. Gender Trouble: Feminism and the Subversion of Identity. London: Routledge, Chapman \& Hall, 1990. Print.

[3] Castle, Terry. The Female Thermometer: Eighteenth-Century Culture and the Invention of the Uncanny. New York: Oxford UP, 1995. Print.

[4] Cohen-Vrignaud, Gerard. "Byron and Oriental Love." Nineteenth-Century Literature 68.1 (2013): 1-32. Web.

[5] Derrida, Jacques. 1991. "Choreographies." A Derrida Reader. Ed. Peggy Kamuf. Trans. Ruben Bevezdivin. New York: Columbia UP, 1991. 440-456. Web.

[6] Elfenbein, Andrew. Byron and the Victorians. Cambridge: Cambridge UP, 1995. Print.

[7] Foucault, Michel. The History of Sexuality: An Introduction. Trans. Robert Hurley. 2 vols. New York: Random House, 1990. Print.

[8] Freud, Sigmund. "Three Essays on Sexuality." The Penguin Freud Library. Ed. James Strachey. Vol. 7. Trans. James Strachey. London: Penguin Books, 1991. Web.

[9] Giuliano, Cheryl Fallon. “'Untold' Feminization of Byron's Oriental Tales." Studies in English Literature, 1500-1900 33.4 (1993): 785-807. Web.

[10] Hartley, David. Observations on Man in Backgrounds of Romanticism. Ed. L. M. Trawick. Bloomington: Indiana UP, 1967. Web.

[11] Horlacher, Stefan, Glomb, Stefan, and Heiler, Lars, eds. Taboo and Transgression in British Literature from the 
Renaissance to the Present. USA: Palgrave Macmillan, 2010.

Web.

[12] Irigaray, Luce. This Sex Which Is not One. Trans. Catherine Porter. New York: Cornell UP, 1985. Print.

[13] Lessenich, Rolf P. "Byron: The Sanity or Madness of SameSex Love.” The Byron Journal 44.2 (2016): 139-149. Web.

[14] Lofdahl, William M. Iconic Androgyne: Byron's Role in Romantic Sexual Counter Culture. Diss. Florida State University College of Arts and Sciences, 2005. Web.

[15] Moore, Thomas, ed. Letters and Journals of Lord Byron: With Notices of his Life. New York: J. and J. Harper, 1830. Print.

[16] Moscovici, Claudia. Gender and Citizenship: The Dialectics of Subject-Citizenship in Nineteenth-Century French Literature and Culture. Lanham, Maryland: Rowman \& Littlefield, 2000. Web.

[17] Jones, David. Sexuality and the Gothic Magic Lantern: Desire, Eroticism and Literary Visibilities from Byron to Bram Stoker. New York: Palgrave Macmillan, 2014. Web.

[18] Marshall, Nowell. "Beyond Queer Gothic Charting the Gothic History of the Trans Subject in Beckford, Lewis, Byron." TransGothic in Literature and Culture. Jolene Zigarovich. Ed. New York: Taylor and Francis, 2018. 25-52. Web.

[19] Stowe, Harriet Beecher. Lady Byron Vindicated. Boston: Fields, Osgood, \& Co., 1870. Print.

[20] Tomasch, Sylvia, and Gilles, Sealy, eds. Text and Territory: Geographical Imagination in the European Middle Ages. Philadelphia: University of Pennsylvania Press, 1998. Print. 